\title{
Women, Work and Empowerment in a Global Era
}

Ruth Pearson

The discussions at the 'Gender Myths and Feminist Fables' workshop reflect a contradiction in our thinking about women and work, a contradiction which is intensifying in an era of increasingly global economic relations and policies. What is it that we are seeking in terms of women's engagement with paid work and employment?

There are two strands which we need to consider. The first is what I have termed "The Engelian myth". This is the view that women's empowerment, or emancipation as it used to be called, lies in their incorporation into the paid workforce; the position that reflects Joan Robinson's oft repeated observation that 'the only thing worse than being exploited by capital is not being exploited by capital'. Certainly the Marxist tradition has long emphasised that identity, and thus political strategy, should be led by the vanguard "working class" and that women's political interests lie in being incorporated, on an equal basis, into that vanguard.

For many feminists and for some time, a lot of emphasis has been laid on the importance of women's paid employment. Within a socialist feminist tradition, the conditions under which women worked were of course highlighted. Particular concern was paid to equal pay, opportunities for promotion, training and progression through the hierarchy, and that women's priorities - such as flexible hours and leave, protection of reproductive health, freedom from harassment and appropriate non-wage benefits were recognised by both trade unions and management.

Another strand of feminist economists' work has focused not just on decision making and rewards in the paid labour force, but on intra-household relations and decision making, foregrounding the variations in (mis-)match between the amount of paid and unpaid work women do, and how - and by whom - income from work gets spent by and on behalf of different household members. Nancy
Folbre's (1986) significant observation, that both Marxist and neo-classical economics treated the household as a "black box" ruled by a benevolent dictator underlined the importance of interrogating the link between women's paid work and the implications for gender relations in the private as well as the public sphere. Subsequent work, not least Amartya Sen's (1990) re-conceptualising of intra-household bargaining as "cooperative conflict", has challenged the automatic assumptions that women's earning capacity automatically translates into empowerment and autonomy. Earning money may extend women's options, as Naila Kabeer (2000) argues, but it also intensifies their workload and responsibilities without necessarily increasing their autonomy.

These unsettling contradictions are very apparent in the ways that we think about women's increasing role in global production - in globally traded garments and electronics, in the supermarket trade in seasonal fruit and vegetables from more temporate climes, in the out-placing of computerrelated services such as data entry and call centre operations. The debates about women's employment in export sectors have raged since the 1970s: does the employment of women in world market factories offer opportunities or exploitation for women in growing numbers of countries in the developing world? While there are sharp exchanges between different positionalities, which argue that factory employment either offers women a chance to be independent of their families, and to have more say in household decision making, others return to the image of the "global sweatshop", or even in the modern-day version of Foucault's electronic panoptican to insist that the work is underpaid, degrading and exploitative. The earlier analysis Diane Elson and I made in the 1980s (Elson and Pearson 1981) that women's subordination could be intensified, decomposed or recomposed by the construction of a new nimble-fingered female labour 
force are swept aside as particular cases studies or standpoints provide different evidence and conclusions. But interestingly, with a few noble exceptions, such as Diane Wolf's (1992) study of 'Factory Daughters' in Indonesia, there have been limited efforts to empirically test theoretical assumptions about the implications of factory work for different groups of women workers in terms of status and power within households and communities.

The Engelian myth has also spread to the debates about microcredit for women. The literature abounds with assertions and refutations about the extent to which borrowing money, being responsible for putting it to a hopefully productive use, repaying it and making some profit, constitutes a path for empowerment of poor women. Again there has been little systematic effort to interrogate the evidence and, particularly in the world of development organisations, a general acceptance that money in women's hands - and the subsequent market-oriented activity it might facilitate, must challenge women's subordination. Of course the debates are more sophisticated than this, with Mayoux (2001), among others, suggesting that it is the collective activity carried out in groups which has often been associated with programmes that offer financial services to the (very) poor, that constitute the basis for empowerment even though women contract individual loans and work on individual (or family-based) small businesses.

But of course, whether women are working in export factories or in credit financed microenterprises, they are generally adding to their domestic responsibilities the task of earning money to support their households. The need for money has intensified over recent decades, with a raft of social services previously provided by the state requiring cash - for school uniforms and medicines if not for school fees and clinic charges. Women's traditional responsibility for the well-being of household members has been monetised by the introduction of user charges and the general commoditisation of different aspects of local economies. Women have to earn money to meet their gendered household responsibilities. Their work burden is often intensified by their incomegenerating activities, but their role and their status can remain unchanged.

How do we respond politically to this situation? On the one hand, like Oxfam we can protest about inequality of wages and bad working conditions for poor women workers in different parts of the world; undoubtedly this continues to be a central issue. We can insist that remuneration and working conditions comply with internationally agreed standards, or codes of conduct as has been done in the vegetable and fruit sector (Barrientos et al. 2000) as well as in manufacturing and that these codes reflect the priorities of women workers (Pearson and Seyfang 2002). We can also examine the ways in which women's contribution to foreign exchange earnings and economic growth can be reflected in the ways in which labour regulation and social policies are organised, rejecting the view that participation in the global economy denies nationstates - and thus women's movements in particular countries - the possibility of locally negotiated settlements about social protection, workplace norms and non-wage benefits (Razavi and Pearson 2004).

There is another issue that connects the two upto-now separate debates about empowerment of women in export production and in credit-supported micro-enterprises. We have tended to assume that factory production for export represents, for women, access to the norm of male employment - that is in the formal regulated economy, with all the concomitant benefits and social protection which such employment signals. Women factory workers, particularly those in manufacturing sectors are thought to have joined the (previously male) labour aristocracy. And we have spent three decades lamenting the fact that very often, via devices such as special (exportprocessing zones) or subcontracting arrangements, women seldom enjoy extensive non-wage benefits. However, it would be more sensible to reconceptualise women's work in most areas of the developing world as being by definition unregulated and unprotected, regardless of whether it takes place in large-scale workplaces, small or family-based workshops or within women's own houses or compounds. Women provide "cheap" labour, which is part of the so-called "informal" economy. The informal economy is not the exception in most developing countries - it is the norm, and by all statistical accounts it is growing both because the formal sector is becoming informalised, and because the range of market-oriented informal economic activities is expanding to meet the needs of poor households for cash. Women are playing a bigger and bigger role in this economy, and policies and demands, which might improve their position, should be based on this reality. 
We also need to acknowledge that the Engelian myth is based on a conceptualisation of work which somehow has remained independent from the extensive analysis in the 1970s, which we then called the 'Domestic Labour Debate' (Molyneux 1979). Although wages for housework was dismissed as an essentialist and radical feminist fantasy, it is time to extract from this something important. Women's participation in the money economy - whether through factory employment, home-based production for nationally and internationally traded goods such as fashion wear or sports shoes, or small-scale trading and services which provide money for daily survival - is not on its own going to achieve women's equality or empowerment.

By the beginning of the twenty-first century, the labour force participation of women had doubled worldwide; but if we add to this women's involvement in all kinds of market-oriented activities, it would be hard to find any group of women who could not be said to be economically active. Poor women, like men, earn their entitlements to adequate returns on their labour, but also to publicly provided resources to ensure that they can cover their responsibilities to their children and other household members. Economic participation is manifold and the entitlements which accrue from it should include, but not be limited to, the ways in which money income can be increased. Poor women need money, but increases in wages will not on their own make women either

\section{References}

Barrientos, S., McClenaghan, S. and Orton, L., 2000, 'Ethical trade and South African deciduous fruit exporters - addressing gender sensitivity', European Journal of Development Research, Vol 12 No 1

Elson, D. and Pearson, R., 1981, "Nimble fingers make cheap workers": an analysis of women's employment in Third World export manufacturing', Feminist Review, Vol 7: 87-107

Folbre, N., 1986, 'Hearts and spades: paradigms of household economics', World Development, Vol 14 No 2: 245-55

Kabeer, N., 2000, The Power to Choose, London: Verso

Mayoux, L., 2001, 'Women's Empowerment Versus Sustainability? Towards a New Paradigm in Micro less poor or more powerful. Improvements in the conditions and returns from work must be coupled with expectations that the state will ensure that they achieve a minimum income; that they have access to affordable and high-quality education, and health and transport services; and that their environment is healthy and their lives are not blighted by community and domestic violence.

Being exploited by capital is the fate of virtually all women in today's global economy, but the exchange value of their labour will not on its own provide the basis for women's empowerment. If we challenge the separation between factory work and home-based work, between the formal and informal sector, we will have a clearer perception of what women's economic and social rights might cover. If we challenge the myth that the poor women have endless resources of time and energy to dedicate to improving the return on their labour in the marginal economies of the informal sector, the role for public policy will become clearer. Demands for international support to improve the working conditions and wages earned by poor women must be linked to explorations of universal entitlements in terms of minimum income and services. It is not reasonable to assume that the improvements required for the genuine empowerment of poor women can come solely from selling their labour without resourcing collective provision of services and rewarding women's responsibilities in reproductive activities.

Finance Programmes', in B. Lemire, R. Pearson and G. Campbell (eds), Women and Credit: Researching the Past: Refiguring the Future, Oxford and New York: Berg

Molyneux, M., 1979, 'Beyond the domestic labour debate', New Left Review, No 115, July/August: 3-28

Pearson, R. and Seyfang, G., 2002, “'I'll Tell You What I Want?": Women Workers and Codes of Conduct', in R. Jenkins, R. Pearson and G. Seyfang (eds), Corporate Responsibility and Labour Rights: Codes of Conduct in the Global Economy, London: Earthscan

Razavi, S. and Pearson, R., 2004, 'Globalization, Export-oriented Employment and Social Policy: Gendered Connections', in R. Pearson, S. Razavi and C. Danloy (eds), Globalization, Export- 
Oriented Employment and Social Policy, Wolf, D., 1992, Factory Daughters: Gender, Household Basingstoke: Palgrave Macmillan Dynamics and Rural Industrialization in Java, Sen, A., 1990, 'Gender and Cooperative Conflict', in I. Tinker (ed.), Persistent Inequalities: Women and World Development, Oxford: Oxford University Press 